Tersedia online di https://jurnal.ugm.ac.id/jsv

\title{
The Efficacy Study of Duramectin, Oxfendazole, Piperazine, and Pyrantel pamoate Against Gastrointestinal Worms In Horses In Yogyakarta Special Region
}

\author{
Studi Efikasi Duramectin, Oxfendazole, Piperazine dan Pyrantel pamoate terhadap \\ Cacing Gastrointestinal pada Kuda di Daerah Istimewa Yogyakarta
}

\author{
Yuriadi*, Ida Tjahajati, Soedarmanto Indarjulianto, Irkham Widiyono \\ Department Internal Medicine, Faculty of Veterinary Medicine, UGM \\ *Email : yuriadi@ugm.ac.id
}

Naskah diterima : 24 Januari 2019, direvisi : 20 Mei 2019, disetujui : 31 Mei 2019

\begin{abstract}
Abstrak
Penelitian ini bertujuan untuk mengetahui efikasi obat cacing duramectin, oxfendazole, piperazine, dan pyrantel pamoate terhadap cacing gastrointestinal pada kuda di Daerah Istimewa Yogyakarta. Sampel penelitian menggunakan 40 ekor kuda yang menderita infeksi cacing gastrointestinal. Semua kuda dilakukan pemeriksaan untuk mengetahui gejala klinis dan pemeriksaan pendukung di laboratorium parasitologi untuk pemeriksaan telur cacing dari feses kuda. Kuda dengan hasil positif terdapat telur cacing dengan jumlah di atas 200 telur per gram feses kuda. Penelitian ini bertujuan untuk menentukan efektifitas obat cacing yang akan digunakan. Penelitian kuda dibagi menjadi empat kelompok perlakuan, masing-masing kelompok terdiri dari sepuluh kuda. Kelompok I diberi duramectin dengan dosis $0,2 \mathrm{mg} / \mathrm{kg}$ berat badan. Kelompok II diberi oxfendazole dengan dosis 7,5 $\mathrm{mg} / \mathrm{kg}$ berat badan, Kelompok III diberi pengobatan Piperazin $125 \mathrm{mg}$ per kilogram berat badan dan Kelompok IV diberi pirantelpamoate dengan dosis $20 \mathrm{mg} / \mathrm{kg}$ berat badan. Setelah menerima pengobatan, kuda-kuda diamati untuk mencatat kemajuan dalam hal gejala klinis dan jumlah dan jenis telur cacing dalam kotoran mereka setiap tiga hari selama empat kali berturut-turut. Hasil data penelitian ditabulasi dan dianalisis secara deskriptif komparatif.

Hasil penelitian menunjukkan berbagai tingkat kemanjuran obat cacing untuk kuda. Oxfendazole dapat membunuh cacing Strongylus dan Parascaris. Duramectin membunuh cacing Strongylus dan mengurangi beberapa cacing Parascaris. Piperazine dan pyrantel pamoate membunuh cacing Strongylus dan mengurangi beberapa Parascaris.
\end{abstract}

Kata kunci: duramectin; kuda; obat cacing; oxfendazole, piperazine, pyrantel pamoate

\begin{abstract}
This research aimed at determining the efficacy of duramectin, oxfendazole, piperazine, and pyrantelpamoate against gastrointestinal worms in horses in Yogyakarta Special Region. The object of research involved 40 horses diagnosed with gastrointestinal worm infection. All of the horses were subjected to examination for clinical symptoms and parasitology laboratory checkup for signs of worm eggs in their feces, and they were pronounced positive for experiment animals with at least 200 eggs per gram of feces per horse. The research horses were weighed to determine the dose of worm medication to be used. The research horses are divided into four treatment groups, each group consists of ten horses. Group I was given duramectin with a dose of $0.2 \mathrm{mg} / \mathrm{kg}$ of body weight. Group II was given oxfendazole with a dose of $7.5 \mathrm{mg} / \mathrm{kg}$ of body weight, Group III was given $125 \mathrm{mg}$ Piperazin treatment per kilogram of body weight and Group IV was given pyrantel pamoate with a dose of $20 \mathrm{mg} / \mathrm{kg}$ of body weight. After receiving themedication, the horses were observed to document the progress in terms of clinical symptoms and the amount and type of worm eggs in their feces every three days for four times in a row. The research data results were tabulated and were descriptive-comparatively analyzed. The research result showed varying efficacy level of worm medication for horses. Oxfendazole kills Strongylus and Parascaris worms. Duramectin kills Strongylus worms and reduce some of the Paraascaris worms. Piperazine and pyrantel pamoate kills the Strongylus worms and reduce some of the Paraascaris.
\end{abstract}

Key words: duramectin; gastrointestinal worms; horses; oxfendazole; piperazine; pyrantel pamoate. 
The Efficacy Study of Duramectin, Oxfendazole, Piperazine, and Pyrantel pamoate Against Gastrointestinal Worms In Horses ...

\section{Introduction}

The incidence of gastrointestinal disease in horses in Yogyakarta Special Region and Central Java in 2012 includes 9 cases of diarhea in horses and 11 cases in young horses, 8 cases of enteritis in young horses, and 19 cases colic in horses (Anonymous, 2012), they were examined and treated by the Yogyakarta Special Region (DIY) and Central Java PORDASI's Mobile Veterinary Clinic in 2011. The results of gastrointestinal worm examinations in those horses showed that there were 39 horses positively infected by Strongylus sp. worms, and 11 horses positively infected by Parascaris $s p$. worms. These phenomena show that gastrointestinal diseases in horses in DIY and Central Java caused by Strongylus $s p$. worms reached $81 \%$ and the ones caused by Parascaris $s p$. worms reached $19 \%$. These incidence of worm infection triggered complaints among veterinary practitioners and it is suspected that gastrointestinal worm infection in horses has become resistant against worm medications generally used in the fields. Alternative actions need to be taken to overcome the high incidence of gastrointestinal parasite diseases so as to ensure the maximum efficacy of treatments.

Delays in handling these cases will lead to loss for horse famers as the infection could set off chronic diarrhea, emaciation, anemia, conception problems, and death. It could also hinder the success of the program to increase horse population in DIY and Central Java areas. One the efforts include the need to evaluate the efficacy of several anthelmintics against gastrointestinal worms in horses. The treatment of gastrointestinal worms in horses is usually not performed under programmed and detailed processes, the efforts have been tentative, and were based on foreign textbooks and were not performed with a research, therefore, the results have not been satisfying.

\section{Materials and Method}

There were 40 horse patients involved in this research, they were all infected by worms to the infestation above 200 eggs in feces, the eggs came from Strongylus sp. and Parascaris sp. worms, the horses were divided into four groups of ten. Each group was then divided into two sub-groups of 5 Strongylus $s p$. infected horses and 5 Parascaris $s p$. infected horses. Group I received $0.2 \mathrm{mg}$ Duramectin treatment of body weight (Gordon, et al., 1981) injected subcutaneously, Group II received 7.5 mg Oxfendazol treatment of body weight (Gordon, et al., 1981), given orally, and Group III was given 125 mg Piperazin treatment of body weight (Gordon, et al., 1981), and Group IV was given 15 mg Pyrantel Pamoate treatment of body weight (Gordon, et al., 1981). For each groups has been administered worm medicine one times treatment. After treatment, the horses were examined on day $3,6,9$, and 12 to determine the number of worm eggs which have been eliminated through their feces.

The worm egg examination results from Laboratory Parasitology Faculty of veterinary Medicine were tabulated and analyzed descriptivecomparatively to determine the efficacy order of anthelmintics against gastrointestinal worms in research horses.

\section{Results and Discussion}

The sample faeces from 40 horses that was infected by gastrointestinal worms were examination with quantitative method. The faeces of each group positive infected by Strongylus sp. and Parascaris $s p$. eggs with various clinical symptoms, including diarrhea, colic, enteritis and emaciation. The number of eggs in each group varied widely. Group I showed 5750 EPG Strongylus sp. and 3600 EPG Parascaris sp. Group II showed 13100 EPG Strongylus sp. and 750 EPG Parascaris sp. Group III showed 15600 EPG Strongylus sp. and 1700 EPG Parascaris sp.. Group IV 
Yuriadi et. al.

showed 17900 EPG Strongylus sp.eggs per gram of

Grup I until Grup IV can see in the Appendices (Tabel 2 feces and 68000 Parascaris sp. eggs per gram of feces. until Table 5).

Table1. Efficacy of Duramectin, Oxfendazol, Piperazin, Pyrantelpamoate against gastrointestinal worms in horses in DIY (Sleman, Kodya Yogyakarta, Bantul) ( $\mathrm{n}=10$ horses)

\begin{tabular}{cccccccc}
\hline $\begin{array}{c}\text { Worm } \\
\text { Medicine }\end{array}$ & $\begin{array}{c}\text { Number of } \\
\text { Horses }\end{array}$ & Type of Worm & $\begin{array}{c}\text { Before treatment } \\
\text { (EPG) }\end{array}$ & \multicolumn{4}{c}{$\begin{array}{c}\text { After Treatment } \\
\text { (days) }\end{array}$} \\
\cline { 5 - 8 } & & & & 3 & 6 & 9 & 12 \\
\hline \multirow{2}{*}{ Duramectin } & 5 & Strongylus $s p$. & 5.750 & 350 & 0 & 0 & 0 \\
& 5 & Parascaris $s p$. & 3.600 & 200 & 300 & 250 & 250 \\
Oxfendazol & 5 & Strongylus $s p$ & 13.100 & 300 & 0 & 0 & 0 \\
& 5 & Parascaris $s p$. & 750 & 0 & 0 & 0 & 0 \\
Piperazin & 5 & Strongylus $s p$. & 15.600 & 1000 & 400 & 200 & 0 \\
Pyrantel & 5 & Parascaris $s p$. & 1.700 & 600 & 300 & 500 & 350 \\
pamoate & 5 & Strongylus $s p$. & 17.900 & 2300 & 300 & 150 & 0 \\
& 5 & Parascaris $s p$. & 68.000 & 1550 & 1100 & 900 & 900 \\
\hline
\end{tabular}

Among research horses, Strongylus sp. and Parascaris $s p$. eggs were positively found. This is in line with the opinions of Blood and Handerson (1989), Soulsby (1982) and Frasser (2005), the two types of worms frequently infect horses and trigger some clinical symptoms such as diarrhea, colic, chronic intestinal inflammation, anemia, and can even cause death. Strongylus sp. infection in horses usually involve Strongylus vulgaris, Strongylus edentates and Strongylus equines (Soulsby, 1982). This is consistent with Levine's opinion (1968) that worm infestation in host animals can be determined by the number of eggs eliminated through defecation. Levine (1994) further explained that worm infestation can be determined by the number of eggs found in the host's feces. If less than 5.000 eggs were found per gram of feces, it is considered as a light infestation, if between 5.000 to 25.000 eggs were found per gram of feces, it is a moderate infestation, if more than 25.000 eggs were found per gram of feces, it is a heavy infestation. In the Table 1, the research results show which anthelmintics are effective for gastrointestinal worms and that they are only capable of reducing the number of worm infestation in horses. This is in agreement with the opinions of Tanu (1972) and Kirk and Bitsner (1985), that there are two types of anthelmintics: femifugum, which can only expel worms from the body, and vermicidum, which can kill the worms.

Table 2. Group I, 10 horses infected by Strongylus sp. and Parascaris sp. which treated with $0.2 \mathrm{mg}$ Duramectin in District Sleman, Kodya Yogyakarta, Bantul

\begin{tabular}{|c|c|c|c|c|c|}
\hline \multirow[t]{2}{*}{ Group I } & \multirow[t]{2}{*}{ Sex } & \multirow[t]{2}{*}{ Age (years) } & \multicolumn{2}{|c|}{ Clinical sign } & \multirow[t]{2}{*}{ Amount of eggs (EPG) } \\
\hline & & & $\mathrm{BCS}$ & Form of faeces & \\
\hline Surani & Female & 8 & 3 & Pasta & 885 Strongylus sp. \\
\hline Giga & Male & 4 & 2 & Pasta & 880 Strongylus $s p$. \\
\hline Cussion Light & Male & 7 & 3 & Pasta & 1250 Strongylus sp. \\
\hline Avanza & Male & 5 & 3 & Profus, kolik & 1400 Strongylus sp. \\
\hline Legian & Male & 4 & 3 & Profus, enterik & 1335 Strongylus sp. \\
\hline Sigi & Female & 6 & 3 & Pasta & 665 Parascaris sp. \\
\hline Sulteng & Male & 2 & 2 & Pasta & 750 Parascaris sp. \\
\hline Kiki & Female & 3 & 3 & Pasta & 650 Parascaris sp. \\
\hline Juki & Male & 3 & 3 & Pasta & 850 Parascaris sp. \\
\hline Miming & Female & 2 & 3 & Pasta & 685 Parascaris sp. \\
\hline Total & & & & & $\begin{array}{l}5750 \text { Strongylus sp. } \\
3600 \text { Parascaris sp. }\end{array}$ \\
\hline
\end{tabular}


The Efficacy Study of Duramectin, Oxfendazole, Piperazine, and Pyrantel pamoate Against Gastrointestinal Worms In Horses ...

Table 3. Group II 10 horses infected by Strongylus sp. and Parascaris sp. which treated with $7.5 \mathrm{mg}$ Oxfendazolin District Sleman, Kodya Yogyakarta, Bantul

\begin{tabular}{|c|c|c|c|c|c|}
\hline \multirow[t]{2}{*}{ Group II } & \multirow[t]{2}{*}{ Sex } & \multirow[t]{2}{*}{ Age (years) } & \multicolumn{2}{|c|}{ Clinical sign } & \multirow[t]{2}{*}{ Amount of eggs (EPG) } \\
\hline & & & $\mathrm{BCS}$ & Form of faeces & \\
\hline Suti & Female & 3 & 3 & Pasta & 13600 Strongylus sp. \\
\hline Andri & Male & 2 & 2 & Pasta & 14500 Strongylus sp. \\
\hline Amin & Male & 6 & 3 & Pasta & 13150 Strongylus sp. \\
\hline Bandon & Male & 5 & 3 & Profus & 11450 Strongylus sp. \\
\hline Kuntho & Male & 4 & 3 & Profus & 12800 Strongylus $s p$. \\
\hline Gisel & Female & 1 & 3 & Pasta & 1045 Parascaris sp. \\
\hline Ronaldo & Male & 1 & 2 & Pasta & 1280 Parascaris $s p$ \\
\hline Sri & Female & 2 & 3 & Pasta & 890 Parascaris sp. \\
\hline Joko & Male & 2 & 3 & Pasta & 285 Parascaris $s p$. \\
\hline Atin & Female & 1 & 3 & Pasta & 250 Parascaris $s p$. \\
\hline Total & & & & & $\begin{array}{l}\text { 13.100 Strongylus } s p \text {. } \\
750 \text { Parascaris } s p .\end{array}$ \\
\hline
\end{tabular}

Table 4. Group III, 10 horses infected by Strongylus sp. and Parascaris sp. which treated $125 \mathrm{mg}$ Piperazinin District Sleman, Kodya Yogyakarta, Bantul

\begin{tabular}{|c|c|c|c|c|c|}
\hline \multirow[t]{2}{*}{ Group III } & \multirow[t]{2}{*}{ Sex } & \multirow[t]{2}{*}{ Age (years) } & \multicolumn{2}{|c|}{ Clinical sign } & \multirow[t]{2}{*}{ Amount of eggs (EPG) } \\
\hline & & & $\mathrm{BCS}$ & Form of faeces & \\
\hline Toyota & Male & 5 & 3 & Pasta & 13200 Strongylus sp. \\
\hline Antonio & Male & 4 & 2 & Pasta & 15120 Strongylus $s p$. \\
\hline Jaryati & Female & 6 & 3 & Pasta & 17680 Strongylus $s p$. \\
\hline Tini & Female & 5 & 3 & Profus & 14200 Strongylus sp. \\
\hline Pambudi & male & 4 & 3 & Profus & 14800 Strongylus $s p$. \\
\hline Bunga & Female & 1 & 3 & Pasta & 1015 Parascaris $s p$. \\
\hline Sobar & Male & 2 & 2 & Pasta & 1230 Parascaris $s p$. \\
\hline Andalas & Male & 1 & 3 & Pasta & 2292 Parascaris $s p$. \\
\hline Dakor & Male & 1 & 3 & Pasta & 2988 Parascaris $s p$. \\
\hline Dulman & Male & 2 & 3 & Pasta & 975 Parascaris sp. \\
\hline Total & & & & & $\begin{array}{l}\text { 15.600 Strongylus } \\
1.700 \text { Parascaris } s p .\end{array}$ \\
\hline
\end{tabular}

Table 5. Group IV, 10 horses infected by Strongylus sp. and Parascaris $s p$. which treated with $15 \mathrm{mg}$ Pyrantel Pamoate in District Sleman, Kodya Yogyakarta, Bantul

\begin{tabular}{|c|c|c|c|c|c|c|}
\hline \multirow[t]{2}{*}{ Group } & \multirow[t]{2}{*}{ IV } & \multirow[t]{2}{*}{ Sex } & \multirow[t]{2}{*}{ Age (years) } & \multicolumn{2}{|c|}{ Clinical sign } & \multirow[t]{2}{*}{ Amount of eggs (EPG) } \\
\hline & & & & $\mathrm{BCS}$ & Form of faeces & \\
\hline Maskina & & Female & 7 & 3 & Pasta & 1650 Strongylus sp. \\
\hline Budi & & Male & 4 & 2 & Pasta & 25500 Strongylus sp. \\
\hline Jarwo & & Male & 3 & 3 & Pasta & 16700 Strongylus sp. \\
\hline Jeram & & Male & 5 & 2 & Profus & 15800 Strongylus $s p$. \\
\hline Waryoto & & Male & 4 & 2 & Profus & 15150 Strongylus sp. \\
\hline Dina & & Female & 1 & 3 & Pasta & 20110 Parascaris sp. \\
\hline Darmin & & Male & 1 & 2 & Pasta & 72300 Parascaris sp. \\
\hline Cika & & Female & 2 & 2 & Profus & 91250 Parascaris sp. \\
\hline Doni & & Male & 1 & 2 & Profus & 93100 Parascaris sp. \\
\hline Sakura & & Female & 1 & 3 & Pasta & 63240 Parascaris $s p$ \\
\hline Total & & & & & & $\begin{array}{l}\text { 17.900 Strongylus } \\
68.000 \text { Parascaris sp. }\end{array}$ \\
\hline
\end{tabular}


Yuriadi et. al.

According to Blood and Handerson (1989), most infected horses suffer from infestation by worms belonging to the genus Strongylus, such as Strongylus vulgaris. Strongylus vulgaris is also known as Delafondia vulgaris, it belongs to Strongylus genus, Strongiloidea family, Strongylida order, Secermentea sub-class and Nematode class (Soulsby, 1982). Large roundworms (ascaris), which often infect horses, can cause acute infection in a young horse. The visible clinical symptoms include acute colic, weakness, emaciation and death which is usually caused by Parascarisequorum (Blood and Handerson, 1989, and Radostits, et al., 2006). Table 6 shows that the Duramectin experiment with a dose of $0.2 \mathrm{mg} / \mathrm{kg}$ of body weight injected subcutaneously was effective to kill Strongylus $s p$. worms, this was evident from feces examination that before treatment there were 5.750 eggs per gram of feces and after treatment, on day 3 there were 350 eggs per gram of feces, and on day 6 Strongylus sp. worm eggs were not found (Table 6). In the case of Parascaris $s p$. worms, Duramectin can only reduce the number of infestation, as shown from the examination that on day 3 , day 6 , day 9 , and day 12 consecutively, 200, 300, 250, and 250 worm eggs were still found per gram of feces (Table 7). This may be caused by the working method of Duramectin which is similar to Avermectin, Duramectin stimulates highaffinity binding of gamma aminobutyric acid, and disrupts chlor pathways and causes cell membrane hyperpolarization, therefore, it hinders neural delivery which causes neural paralysis on nematode worm peripheral muscles and is less capable to penetrate the brain blood barrier (Subronto and Tjahayati, 2001).

The experiment using Oxfendazol with a dose of $7.5 \mathrm{mg} / \mathrm{kg}$ body weight orally (Gordon, et al., 1981), Effectively kills Strongylus sp.danParascaris $s p$. worms, this is evident from worm egg examinations in the horses's feces on day 6, day 9, and day 12 that showed no Strongylussp (Table 8). worm eggs. In the case of Parascaris sp., on day 3, day 6, day 9, and day 12, eggs were not found (Table 9). This is in line with the opinion of Brander, et al., (1982), this medicine is effective against nematodes, trematodes and cestodes. Oxfendazol's working method is by blocked the worm's fumarate reductase enzymes and hindering its glucose extraction and influencing its glycogen metabolism, this causes inability of the worm's interstitial cells to absorb food so that the worm runs out of glycogen and is unable to produce ATP (Subronto and Tjahayati, 2001; Rossoff, 1990; Adam, 1995).

Table 6. Efficacy of Duramectin to Strongylus sp. in horse (District Sleman, Kodya Yogyakarta, Bantul)

\begin{tabular}{cccccccc}
\hline $\begin{array}{c}\text { Worm } \\
\text { Medicine }\end{array}$ & $\begin{array}{c}\text { Number of } \\
\text { Horses }\end{array}$ & Type of Worm & $\begin{array}{c}\text { Before treatment } \\
(\mathrm{EPG})\end{array}$ & \multicolumn{3}{c}{$\begin{array}{c}\text { After Treatment } \\
\text { (days) }\end{array}$} \\
\cline { 5 - 8 } & & & & 3 & 6 & 9 & 12 \\
\hline Duramectin & 5 & Strongylus $s p$ & 5.750 & 350 & 0 & 0 & 0 \\
& 5 & Parascaris $s p$. & 3.600 & 200 & 300 & 250 & 250 \\
Oxfendazol & 5 & Strongylus $s p$. & 13.100 & 300 & 0 & 0 & 0 \\
& 5 & Parascaris $s p$. & 750 & 0 & 0 & 0 & 0 \\
Piperazin & 5 & Strongylus $s p$. & 15.600 & 1000 & 400 & 200 & 0 \\
Pyrantel & 5 & Parascaris $s p$. & 1.700 & 600 & 300 & 500 & 350 \\
pamoate & 5 & Strongylus $s p$. & 17.900 & 2300 & 300 & 150 & 0 \\
& 5 & Parascaris $s p$. & 68.000 & 1550 & 1100 & 900 & 900 \\
\hline
\end{tabular}


The Efficacy Study of Duramectin, Oxfendazole, Piperazine, and Pyrantel pamoate Against Gastrointestinal Worms In Horses ...

Table 7. Efficacy of Duramectin to Parascaris sp. (District Sleman, Kodya Yogyakarta, Bantul)

\begin{tabular}{|c|c|c|c|c|c|c|c|}
\hline \multirow[t]{2}{*}{ Worm Medicine } & \multirow[t]{2}{*}{$\begin{array}{l}\text { Number of } \\
\text { Horses }\end{array}$} & \multirow[t]{2}{*}{ Type of Worm } & \multirow[t]{2}{*}{$\begin{array}{l}\text { Before treatment } \\
\text { (EPG) }\end{array}$} & \multicolumn{4}{|c|}{$\begin{array}{c}\text { After Treatment } \\
\text { (days) }\end{array}$} \\
\hline & & & & 3 & 6 & 9 & 12 \\
\hline Duramectin & Sigi & Parascaris sp. & 665 & 50 & 80 & 50 & 50 \\
\hline Duramectin & Sulteng & Parascaris sp. & 750 & 40 & 80 & 50 & 50 \\
\hline Duramectin & Kiki & Parascaris $s p$ & 650 & 20 & 40 & 50 & 50 \\
\hline Duramectin & Juki & Parascaris $s p$ & 850 & 45 & 50 & 50 & 50 \\
\hline Duramectin & Miming & Parascaris $s p$. & 685 & 45 & 50 & 50 & 50 \\
\hline Duramectin & 5 horses & Parascaris sp. & 3600 & 200 & 300 & 250 & 250 \\
\hline
\end{tabular}

Table 8. Efficacy of Oxfendazol to Strongylus sp. (District Sleman, Kodya Yogyakarta, Bantul)

\begin{tabular}{|c|c|c|c|c|c|c|c|}
\hline \multirow[t]{2}{*}{$\begin{array}{l}\text { Worm } \\
\text { Medicine }\end{array}$} & \multirow[t]{2}{*}{$\begin{array}{l}\text { Number of } \\
\text { Horses }\end{array}$} & \multirow[t]{2}{*}{ Type of Worm } & \multirow[t]{2}{*}{$\begin{array}{l}\text { Before treatment } \\
\text { (EPG) }\end{array}$} & \multicolumn{4}{|c|}{$\begin{array}{l}\text { After Treatment } \\
\text { (days) }\end{array}$} \\
\hline & & & & 3 & 6 & 9 & 12 \\
\hline Oxfendazol & Suti & Strongylus sp. & 13600 & 45 & 0 & 0 & 0 \\
\hline Oxfendazol & Andri & Strongylus sp. & 14500 & 60 & 0 & 0 & 0 \\
\hline Oxfendazol & Amin & Strongylus sp. & 13150 & 95 & 0 & 0 & 0 \\
\hline Oxfendazol & Bandon & Strongylus sp. & 11450 & 50 & 0 & 0 & 0 \\
\hline Oxfendazol & Kuntho & Strongylus sp. & 12800 & 50 & 0 & 0 & 0 \\
\hline Oxfendazol & 5 horses & Strongylus sp. & 13.100 & 300 & 0 & 0 & 0 \\
\hline
\end{tabular}

The experiment using Piperazin with a dose of $125 \mathrm{mg} / \mathrm{kg}$ of body weight (Gordon, et al., 1981) against Strongylus sp. worms shows that no eggs were found as the result of examination on day 12. This means that the use of Piperazin for Strongylus $s p$. worms in horses is effective, because it can kill the worms on day 12 (Table 10). In the case of Parascaris $s p$. worms, Piperazin can only reduce its infestation in horses. This is evident from the results of worm eggs examination after experiment on day 3 , day 6 , day 9 , and day 12 consecutively, they showed 600, 300, 500, and 350 eggs per gram of feces, consecutively (Appendices Table 11). This is consistent with the opinion of Yordan and Ewing (1980), that Piperazin works by preventing and blocking neuromuscular impulses on myoneural junctions of the worms, similar to the workings of anticholinergic compounds. Additionally, the worm's subsinate acid production is also hindered, so that the worm is intoxicated, paralyzed, and loses grabs on the intestine (Mutschler, 1991), and due to intestinal peristaltic movements, the worms were eliminated passively, alive (Yordan and Ewing, 1980). Ganiswarna (1995) also opines that Piperazin works by intoxicating and paralyzing the worms, working as anticholinergic and causing muscle hyperpolarization so that the worms experience energy loss and, finally, paralysis (Mutschler, 1991). 
Yuriadi et. al.

Table 9. Efficacy of Oxfendazol to Parascaris sp.(District Sleman, Kodya Yogyakarta, Bantul)

\begin{tabular}{|c|c|c|c|c|c|c|c|}
\hline \multirow[t]{2}{*}{ Worm Medicine } & \multirow[t]{2}{*}{$\begin{array}{c}\text { Number of } \\
\text { Horses }\end{array}$} & \multirow[t]{2}{*}{ Type of Worm } & \multirow[t]{2}{*}{$\begin{array}{l}\text { Before treatment } \\
\text { (EPG) }\end{array}$} & \multicolumn{4}{|c|}{$\begin{array}{c}\text { After Treatment } \\
\text { (days) }\end{array}$} \\
\hline & & & & 3 & 6 & 9 & 12 \\
\hline Oxfendazol & Gisel & Parascaris sp. & 1045 & 0 & 0 & 0 & 0 \\
\hline Oxfendazol & Ronaldo & Parascaris sp. & 1280 & 0 & 0 & 0 & 0 \\
\hline Oxfendazol & Sri & Parascaris sp. & 890 & 0 & 0 & 0 & 0 \\
\hline Oxfendazol & Joko & Parascaris sp. & 285 & 0 & 0 & 0 & 0 \\
\hline Oxfendazol & Atin & Parascaris sp. & 250 & 0 & 0 & 0 & 0 \\
\hline Oxfendazol & 5 horses & Parascaris sp. & 750 & 0 & 0 & 0 & 0 \\
\hline
\end{tabular}

Table 10. Efficacy of Piperazin to Strongylus sp. (District Sleman, Kodya Yogyakarta, Bantul)

\begin{tabular}{llllllll}
\hline $\begin{array}{l}\text { Worm } \\
\text { Medicine }\end{array}$ & $\begin{array}{l}\text { Number of } \\
\text { Horses }\end{array}$ & Type of Worm & $\begin{array}{l}\text { Before treatment } \\
\text { (EPG) }\end{array}$ & \multicolumn{4}{l}{$\begin{array}{l}\text { After Treatment } \\
\text { (days) }\end{array}$} \\
\cline { 4 - 7 } & & & 3 & 6 & 9 & 12 \\
\hline Piperazin & Toyota & Strongylus $s p$. & 13200 & 200 & 40 & 30 & 0 \\
& & & & & & & \\
Piperazin & Antonio & Strongylus $s p$. & 15120 & 200 & 30 & 50 & 0 \\
Piperazin & Jaryati & Strongylus $s p$. & 17680 & 200 & 30 & 40 & 0 \\
Piperazin & Tini & Strongylus $s p$. & 14200 & 200 & 150 & 40 & 0 \\
Piperazin & Pambudi & Strongylus $s p$. & 14800 & 200 & 150 & 40 & 0 \\
Piperazin & 5 horses & Strongylus $s p$. & 15.600 & 1000 & 400 & 200 & 0 \\
\hline
\end{tabular}

Table 11. Efficacy of Piperazin to Parascaris sp. (District Sleman, Kodya Yogyakarta, Bantul)

\begin{tabular}{llllllll}
\hline Worm Medicine & $\begin{array}{l}\text { Number of } \\
\text { Horses }\end{array}$ & Type of Worm & $\begin{array}{l}\text { Before treatment } \\
\text { (EPG) }\end{array}$ & \multicolumn{4}{l}{$\begin{array}{l}\text { After Treatment } \\
\text { (days) }\end{array}$} \\
\cline { 5 - 8 } & & & & 3 & 6 & 9 & 12 \\
\hline Piperazin & Bunga & Parascaris $s p$. & 1015 & 200 & 50 & 100 & 90 \\
Piperazin & Sobar & Parascaris $s p$. & 1230 & 130 & 50 & 100 & 80 \\
Piperazin & Andalas & Parascaris $s p$. & 2292 & 90 & 60 & 100 & 60 \\
Piperazin & Dakor & Parascaris $s p$. & 2988 & 90 & 80 & 100 & 60 \\
Piperazin & Dulman & Parascaris $s p$. & 975 & 90 & 60 & 100 & 60 \\
Piperazin & 5 horses & Parascaris $s p$. & 1.700 & 600 & 300 & 500 & 350 \\
\hline
\end{tabular}

The effectiveness of Pyrantel pamoate with a dose of $15 \mathrm{mg} / \mathrm{kg}$ of body weight given orally against Strongylus sp. worms is good, this is evident from the results of examinations on day 12 where no eggs were found in the feces (Table 12). However, against Paracaris $s p$. worms in horses, this medicine succeeds only to reduce the level of infestation. This is proven from examination for Parascaris sp. eggs on day 3 , day 6, day 9, and day 12 after treatment, the number decreases from 68.000 eggs per gram of feces to 1.550 , $11.000,900,900$ eggs per gram of feces, consecutively
(Table 13). This means that Pyrantel pamoate is not effective to kill Parascaris sp. worms, it can only reduce the level of infestation. This is probably because Pyrantel pamoate as an anthelmintic treatment works similar to excessive stimulation of acethylcholine on neuromuscular joints which get continuously and excessively excited into paralysis (nicotine-like effect) (Levine, 1994). The worms experience paralysis due to excessive muscular spasms so that they get eliminated together with excrements (Duncan, 1983 and Katzung, 2004). 
The Efficacy Study of Duramectin, Oxfendazole, Piperazine, and Pyrantel pamoate Against Gastrointestinal Worms In Horses ...

Table 12. Efficacy of Pirantel pamoat to Strongylus sp. (District Sleman, Kodya Yogyakarta, Bantul)

\begin{tabular}{clllllll}
\hline Worm Medicine & $\begin{array}{l}\text { Number of } \\
\text { Horses }\end{array}$ & Type of Worm & $\begin{array}{l}\text { Before treatment } \\
\text { (EPG) }\end{array}$ & \multicolumn{4}{l}{$\begin{array}{l}\text { After Treatment } \\
\text { (days) }\end{array}$} \\
\cline { 5 - 8 } & & & & 3 & 6 & 9 & 12 \\
\hline Pirantel pamoat & Maskina & Strongylus $s p$. & 1650 & 180 & 50 & 10 & 0 \\
& & & & & & & \\
Pirantel pamoat & Budi & Strongylus $s p$. & 25500 & 190 & 60 & 10 & 0 \\
Pirantel pamoat & Jarwo & Strongylus $s p$. & 16700 & 580 & 65 & 50 & 0 \\
Pirantel pamoat & Jeram & Strongylus $s p$. & 15800 & 750 & 75 & 60 & 0 \\
Pirantel pamoat & Waryoto & Strongylus $s p$. & 15150 & 600 & 50 & 20 & 0 \\
Pirantel pamoat & 5 horses & Strongylus $s p$. & 17.900 & 2300 & 300 & 150 & 0 \\
\hline
\end{tabular}

Table 13. Efficacy of Pirantel pamoat to Parascaris sp.in District Sleman, Kodya Yogyakarta, Bantul)

\begin{tabular}{clllllll}
\hline Worm Medicine & $\begin{array}{l}\text { Number of } \\
\text { Horses }\end{array}$ & Type of Worm & $\begin{array}{l}\text { Before treatment } \\
(\text { EPG })\end{array}$ & \multicolumn{4}{l}{$\begin{array}{l}\text { After Treatment } \\
\text { (days) }\end{array}$} \\
\cline { 5 - 8 } & & & & 3 & 6 & 9 & 12 \\
\hline Pirantel pamoat & Dina & Parascaris $s p$. & 20110 & 80 & 50 & 30 & 30 \\
Pirantel pamoat & Darmin & Parascaris $s p$. & 72300 & 70 & 60 & 30 & 30 \\
Pirantel pamoat & Cika & Parascaris $s p$. & 91250 & 380 & 340 & 300 & 300 \\
Pirantel pamoat & Doni & Parascaris $s p$. & 93100 & 250 & 200 & 150 & 150 \\
Pirantel pamoat & Sakura & Parascaris $s p$. & 63240 & 720 & 450 & 390 & 390 \\
Pirantel pamoat & 5 horses & Parascaris $s p$. & 68.000 & 1550 & 1100 & 900 & 900 \\
\hline
\end{tabular}

\section{Conclusion}

Oxfendazole is found effective to kill Strongylus sp. and Parascaris sp. worms in horses. Duramectin, Piperazin, and Pyrantelpamoate are found effective to kill Strongylus sp.worms, but they succeed only to reduce Parascaris $s p$. worm infestation in horses.

\section{Acknowledge}

Thank you for support from PPDH FKH

UGM that give funding for this rsearch.

\section{References}

Anonymous. (2012). Laporan Tahunan Klinik Hewan Keliling PORDASI DIY danJawa Tengah.

Adams, R. H. (1995).Veterinary Pharmacology and Therapeutic, $7^{\text {th }}$ Edition. Iowa StateUniversity Press. Ames.

Blood, D. C., dan Handerson, J. A. (1989). Veterinary
Medicine $5^{\text {th }}$ Edition. Lea and Febiger, Pliladelphia.Pp. 767-768.

Brander, G. C. dan Pugh, D. M., Bywater, R.I., dan Jenkins, W.L. (1991). VeterinaryApplied Pharmacology and Therapeutics, $5^{\text {th }}$ Edition.BailliereTindall, British.

Duncan, J. (1983). Anthelmintics for Use in Equine Practice. Pharmacological Basis of Large Animal Medicine Eds. Bogan, J. A., et al. Blackwell Scientific Publication. Oxford.

Frasser, C. M. (2005). The Merck Veterinary Manual: a Handbook of Diagnosis, Therapy, and Disease. Blackwell Publishing. USA.

Ganiswarna, Sulistia G. (1995). Farmakologi dan terapi, Edisi keempat. Bagian Farmakologi Fakultas Kedokteran Universitas Indonesia. Jakarta.

Gordon, L. C., Edward, H., Walter, E. W., Glen, J. S., dan Richard, B. K. (1981). Formulary. Purdue University School of Veterinary Medicine.

Katzung, B. G. (2004). Farmakologi Dasar dan Klinik. Bagian Farmakologi Fakultas Kedokteran Universitas Airlangga. 
Yuriadi et. al.

Kirk, R.W., Bistner, S.I. (1985). Hand book of

Rosoff, L. S. (1990). Handbook of Veterinary Drugs $2^{\text {nd }}$ $E d$. Springer Publisher Company. New York. Veterinary Procedures and Emergency Treatment. 4th Ed. W.B. Saunders Co. Philadelphia. P928.

Levine, N. D. (1968). Nematoda Parasites of Domestic Animals and Man. Burgess Publishing Company. Minneapolis. Hal. 185-189.

Levine, N. D. (1994). Parasitologi Veteriner. Gadjah Mada University Press.

Mutschler, E. (1991). Dinamika Obat. ITB Bandung.

Radostits, O. M., Gay, C. C., Hinchcliff, K. W., Constable. P. D. (2006). Veterinary Medicine a Textbook of the Disease of Cattle, Horses, Sheep, Pigs and Goat $10^{\text {th }} \mathrm{Ed}$. Saunders Elsevier. USA.

Soulsby, E.J.L., 1982. Helminth, Anthropods and Protozoa of Domesticated Animal. 7th $e d$.ELSB and Bailliere Tindal, London. Hal. 313-314.

Subronto, P. danTjahayati, I. (2001). IlmuPenyakitTernak II. Gadjah Mada University Press, Yogyakarta. Hal. 397-399.

Tanu, I. (1972).Anthelmintika dalam Farmakologi dan Terapi, Bagian Farmakologi, FKUI, Jakarta.

Yordan, H. E. dan Ewing, S. A. (1980). Concepts of Gastro-intestinal Parasitism and Strategies for Designing Corrective and Control Programs.Veterinary Gastroenterology Ed. Anderson, N. V. Lea and Febiger. Philadelphia. 